DOI: 10.46340/eppd.2021.8.5.4

Mykyta Yevdomakha

ORCID ID: https://orcid.org/0000-0001-6889-1653

Taras Shevchenko National University of Kyiv, Ukraine

\title{
POLITICAL MECHANISMS AND TOOLS FOR IMPLEMENTING ENVIRONMENTAL PROGRAMS OF THE EUROPEAN UNION
}

\author{
Микита Євдомаха \\ Київський національний університет імені Тараса Шевченка, Україна

\section{ПОЛІТИЧНІ МЕХАНІЗМИ ТА ІНСТРУМЕНТИ РЕАЛІЗАЦІЇ ЕКОЛОГІЧНИХ ПРОГРАМ ЄВРОПЕЙСЬКОГО СОЮЗУ}

The article is focused on the use of the special mechanisms and tools used by the European Union to implement the environmental programs. The EU is an influential actor in the global arena, with regards to environmental policy making, setting out the trends, main principles, and being the example for other countries. This article examines the evolution of the mechanisms and tools throughout history with a focus on their main components and the reasons for their success. The article contains a critical analysis of the historical development of the legal basis and policy-related tools through treaty reforms and environmental programs adoption, with noting the influence of each historical step on the evolution of today's environmental programs of the EU. Subsequent research in the article assessed the changes introduced to the mechanisms and tools following the membership enlargements, and the need to balance the dramatic differences in each country's environmental approach. Along with that, the research examined how the European Union's policy-making in the field of the environment was affected by the changes in other international organizations and countries, including the multilateral treaties and agreements. The article concludes that the level of influence of the European Union has been incremental and sufficient, with the global level scale. The EU's principles on the environmental policy are witnessed in many other countries' policies, international multilateral and bilateral agreements, as well as in the rhetoric of the politicians. Thus, the article comes to the conclusion that the European Union has formed an effective system of the instruments and tools of the environmental policy, which nowadays serves as the reliable background of the rational use of natural resources. These methods secure a somewhat balanced transformation of the negative factors of nature use by humans, along with promoting and stimulating the positive effects and ways of cooperation with nature. This is considered to be of great importance, as nowadays, only the widespread use of economic mechanisms for environmental protection will stimulate the pro-ecological behavior of economic entities and society as a whole, globally. Using the positive experience of the European Union, in general, and its member countries, in particular, in the implementation of economic instruments makes it possible to address environmental policies around the world more effectively.

Keywords: environmental program, policy making, soft power, ecology, natural resources.

Актуальність даного дослідження зумовлена зміною контексту використання влади і джерел цієї влади, зважаючи на мінливість сучасного світу. Поряд із традиційними концепціями влади екологічна політика зайняла вагоме місце серед інструментів держав та організацій. I попри те, що екологічна політика $\epsilon$ порівняно новим інструментом на міжнародній арені у вже названих агентів, деякі з останніх зуміли досить вміло нею скористуватися та обернути на стратегічну перевагу. Мова іде про Європейське Співтовариство, в еволюції якого екологічна політика займає одне із провідних місць, при чому, ще з 70-х років 20 століття. Окрім того, уже більше півстоліття екологічна політика ЄC формує глобальну тенденцію використання екології як «м'якої сили», виступаючи одним із лідерів серед задання її напряму. 
Екологічна політика - це системна діяльність держави та суспільства у цілому щодо збереження та раціонального використання і відновлення природних ресурсів, забезпечення сталого розвитку та мінімізацію негативного впливу людини на навколишнє середовище ${ }^{1}$.

У дискусіях про екологічну політику слід відділяти такі поняття як «екологічна політика» та «політика щодо навколишнього середовища». I якщо у вітчизняній науковій літературі ці два поняття $є$ дуже схожими і їх часто взаємо замінюють, то більш очевидним $\epsilon$ їх різниця англійською мовою - «ecological policy» та «environmental policy». На відміну від політики щодо навколишнього середовища, екологічна політика розглядає питання, спрямовані на досягнення вигод (як грошових, так і негрошових) від екології поза людською діяльністю. Екологічна політика включає управління природними ресурсами (рибальство, лісове господарство, дика природа, ареал, біорізноманіття). Цей спеціалізований напрям політики має свої відмінні риси².

Цікаво, що поступове розширення та консолідація дій Свропейського Союзу у галузі охорони навколишнього середовища йде паралельно із еволюцією та трансформацією самого об'єднання. Відмітимо, що навіть відсутність екологічної складової у Договорі про заснування Європейського економічного співтовариства $(\mathrm{EEC})^{3}$ не завадило діям $Є С$ у цій сфері. Головний здобуток на сьогоднішній день - це те, що із неузгодженого набору ідей та спроб, екологічна політика ЄС стала однією із найбільш показових у світі.

Серед принципів та цілей Європейської Спільноти слід згадати сприяння «гармонійному розвитку економічної діяльності», «підвищення рівня життя» та «постійне покращення умов життя та праці свого народу» ${ }^{4}$.

Зростаюче занепокоєння громадськості щодо навколишнього середовища та важливі паралельні події на міжнародному рівні, включаючи Стокгольмську декларацію про навколишнє середовище людини 1972 року, стали важливими каталізаторами для більш чіткої та продуманої ролі ЄС в екологічному секторі. Даний документ став першим на міжнародному рівні та ліг в основу міждержавної та міжнародної співпраці усфері природокористування. Важливим з точки зору формування концептуальних підходів до формування державами екологічної політики стали принципи Декларації, а саме право на сприятливі умови життя у навколишньому природному середовищі, якість якого дозволяє вести гідне життя при одночасній відповідальності за охорону довкілля, покращення його якості, підтримці вироблення відновлювальних ресурсів, плануванні економічного розвитку збереження природи, поєднанні екологічного, економічного та соціального розвитку, підвищенні існуючого та майбутнього потенціалу розвитку країн, що розвиваються, забезпеченні раціональнішого управління ресурсами, проведенні якісної демографічної політики, проведенні ефективної інформаційно-просвітницької діяльності щодо екологічних проблем, охорони природи та покращення стану довкілля в усіх аспектах, пов'язаних з діяльністю людини, позбавлені наслідків застосування ядерної та інших видів зброї масового ураження, прагненні якнайшвидшого досягнення домовленостей щодо ліквідації та повного знищення таких видів зброї5.

Європейським Союзом були прийняті чотири послідовні програми, які засновувалися на вертикальному та секторальному підходах до розв'язання екологічних проблем ${ }^{6}$. Вони діяли до 1992 року і як наслідок мали прийнятими більше двох сотень актів, які стосувалися питань

\footnotetext{
${ }^{1}$ Волинець, В. (2012). Екологічна функція в системі функцій держави: проблеми правового забезпечення в Україні. Юридична Україна, 11, 4-11; Малиш, Н. А. (2009). Екологічна політика: конфліктність, стратегія, тактика. Вісник Національної академії управління при Президенті Украӥни, 1, 1-7; Посталовская, О. (2016). Институтьь и механизмы реализации экологической политики в современном обществе. Минск, 23; Головкін, О. (2011). Державний контроль та нагляд в сфері охорони довкілля як складова екологічної політики України. Часопис Київського університету права, 4, 290-293; Benson, D., Jordan, А. (2015). Environmental Policy. International Encyclopedia of Social and Behavioural Sciences. Oxford: Elsevier.

${ }^{2}$ Lackey, R. (2006). Axioms of ecological policy. Fisheries, 31 (6), 286-290.

${ }^{3}$ EUR-Lex (1957). Treaty Establishing the European Economic Community (EEC)

$<$ https://eur-lex.europa.eu/legal-content/EN/ALL/?uri=CELEX\%3A11957E\%2FTXT> (2021, червень, 30).

${ }^{4}$ Там само.

${ }^{5}$ Конференции Организации Объединенных Наций по проблемам окружающей человека среды (1970). Стокгольмская деклараиия <https://www.un.org/ru/documents/decl_conv/declarations/declarathenv.shtml> (2021, червень, 30).

${ }^{6}$ Мовчан, Ю. (2021). Політика ЄС у сфері охорони довкілля. Офіиійний сайт Міністерства юстиції Украӥни <https://minjust.gov.ua/m/str_2971> (2021, червень, 30).
} 
скорочення забруднення та запровадження мінімальних стандартів щодо збирання та утилізації відходів, забруднення води та повітря. Саме у 1972 році був зроблений вперше акцент на охорону середовища існування людини, i започаткування екологічної політики урамках існування i функціонування Європейського Союзу. Це було можливим за умови створення відповідного підгрунтя, частиною якого слали відповідні організаційні структури та прийняття правових актів.

У 1973 р. була створена Служба охорони навколишнього середовища та захисту споживачів, i була прийнята перша Програма екологічних дій. Ці ініціативи сприяли рішучому включенню екологічних проблем у політичний порядок денний $\mathrm{CC}$ і часто визначаються як відправна точка еволюції екологічної політики $\mathrm{CC}^{1}$.

Екологічна політика $Є \mathrm{C} є$ систематичною, структурованою і регулярно переглядається, зважаючи на потреби часу. Кожен із етапів формування екологічної політики ЄС зводиться до окремої екологічної програми.

Перша ПЕД забезпечувала лише широкі рамки принципів та цілей. Однак вона розпочала практику Свропейської Комісії в екологічній галузі.

Екологічна політика СС почала ставати більш послідовною протягом 1980-х років. Третя ПЕД (1982-1986 рр.) сприяла формуванню напрямку екологічного законодавства та політики СС на цьому етапі. Зокрема, вона наголосила на запобіганні та суворому підході, заснованому на скороченні викидів, а не на підході, орієнтованому на якість, який, натомість, залишив би державам-членам можливість визначити найбільш економічно ефективні шляхи досягнення цілей якості навколишнього середовища ${ }^{2}$. Вона також підкреслила важливість моніторингу Комісії для ефективності екологічного законодавства.

Єдиний європейський акт (СЄА), прийнятий у 1986 р., ввів чітку правову основу для екологічного законодавства на європейському рівні, тим самим представляючи значний крок вперед у процесі поступової консолідації європейської екологічної політики. Відповідно до ст. 130 (зараз ст. 192-93) Договору про функціонування Європейського Союзу (ДФЄС) - Рада, приймаючи рішення одноголосно та за погодженням з Свропейським Парламентом (ЄП), наділялася конкретними повноваженнями щодо екологічної політики ${ }^{3}$. Хоча на практиці вимога одностайності залишила попередню практику практично незмінною, символічне значення наявності чітко визначеної правової основи для природоохоронних дій було величезним. Створення цієї Ради дозволило проактивно приймати СС рішення у галузі навколишнього середовища. Вона представила деякі ключові принципи екологічної політики СС, таких як принцип «превентивних дій», ідею про те, що екологічна шкода має бути пріоритетним завданням у ії джерела, та «забруднювач платить».

Новий підхід, який відображав виникаючі на той час теорії екологічної модернізації ${ }^{4}$, знайшов офіційне підтвердження у Четвертій ПЕД (1987-1992), яка визнала екологічне регулювання основою для «тривалого економічного та соціального прогресу» ${ }^{5}$. Загалом, 1980-ті роки виявилися плідним періодом з точки зору природоохоронної діяльності. У той же час, зростаюча кількість проваджень, порушених Комісією проти держав-членів, почала викликати серйозні занепокоєння щодо реальної ефективності такого законодавства та переключила увагу на ефективність та необхідність впровадження екологічного права.

Наприкінці 1980-х років Європейська Комісія почала досліджувати інші інструменти екологічної політики з метою сприяння залученню приватних суб'єктів до імплементації екологічних норм. Таким чином, екологічне законодавство ЄС у цей період передбачало прийняття інноваційних заходів, утому числі щодо екологічного маркування, доступу громадськості

\footnotetext{
${ }^{1}$ Orlando, E. (2013). The Evolution of EU Policy and Law in the Environmental Field: Achievements and Current Challenges. The Transatlantic Relationship and the future Global Governance.

<http://www.iai.it/sites/default/files/TW_WP_21.pdf> (2021, червень, 30).

${ }^{2}$ Hanf, K. (1997). Air Pollution Policy in the European Union. Environmental Law and Policy in the European Union and the United States, 125-146.

${ }^{3}$ Eur-Lex (1957). Treaty Establishing the European Economic Community (EEC) <https://eur-lex.europa.eu/ legal-content/EN/ALL/?uri=CELEX\%3A11957E\%2FTXT> (2021, червень, 30).

${ }^{4}$ Weale, A. (1996). Environmental Rules and Rule-Making in the European Union. Journal of European Public Policy, 3, 4, 594-611.

${ }^{5}$ Eur-Lex (1987). Resolution on the continuation and implementation of a European Community policy and action programme on the environment <http://eur-lex.europa.eu/LexUriServ/LexUriServ.do?uri=celex:41987x1207:en:not> (2021, червень, 30).
} 
до екологічної інформації, оцінки впливу на навколишнє середовище та пропозиції щодо директиви, що встановлює цивільну відповідальність за відходи ${ }^{1}$. 3 інституційної точки зору в ЄС вже функціонували Європейське агентство з навколишнього середовища та Європейська мережа 3 питань екологічної інформації та спостережень.

Суттєвий вплив на еволюцію екологічної політики ЄС та масштабів, яких вона набрала, відіграв Європейський суд. Європейський суд з самого початку відігравав фундаментальну роль у розробці та консолідації екологічної політики спільноти. Прецедентна практика Суду легітимізувала внутрішні та зовнішні дії у галузі навколишнього середовища. У трактуванні загальних положень Договору, Європейський суд вважав, що екологічна політика потрапляє до сфери компетенції як «прихована влада» ${ }^{2}$ У правовому сенсі таких підхід пояснювався тим, що екологічні заходи можуть базуватися на статті 114 ДФЄС (в тій мірі, в якій вони мають на меті досягти цілі внутрішнього ринку), та на статті 352 ДФЄС, оскільки вони можуть бути необхідними для досягнення цілей ЄС «у сфері захисту навколишнього середовища та поліпшення якості життя» ${ }^{3}$.

Існування різних процедур прийняття рішень та різних вимог щодо голосування для прийняття законодавчих заходів, пов'язаних із внутрішнім ринком та навколишнім середовищем, було покладено в основу справи про діоксид титану ${ }^{4}$. Справа стосувалася скасування Директиви 89/428 про гармонізацію національних правил щодо зменшення забруднення, спричиненого відходами промисловості діоксиду титану. Суд заявив, що Директива цілком може базуватися на статті 100а ДФСС (внутрішній ринок), яка вимагає голосування кваліфікованою більшістю голосів у Раді, замість 130-ї (навколишнє середовище), що вимагає одностайності. Цей випадок уособлює інституційну боротьбу між міжурядовою позицією, представленою Радою, та наднаціональним підходом Комісії. Рішення Суду було особливо важливим для еволюції екологічної політики та 3'ясування ролі Суду як важливого двигуна фундаментальних політичних змін. Рішення Суду відкрило шлях до розширення голосування кваліфікованою більшістю в екологічній галузі. Зрештою такий крок вперед був зроблений в Маастрихтському договорі.

Маастрихтський договір (1992р.) додав конкретне посилання на принцип обережності серед керівних принципів екологічної політики $Є С$ і надав більш чітке пояснення принципу екологічної інтеграції ${ }^{5}$. Що ще важливіше, обидва Договори сприяли подальшому зміцненню екологічних основ екологічного права та політики ЄС. Зокрема, Маастрихтський договір вперше представив конкретне посилання на охорону навколишнього середовища серед цілей Європейського Союзу.

Амстердамський договір (1997р.) доповнив це, додавши посилання на сталий розвиток серед цілей Союзу та чітко згадавши досягнення «високого рівня захисту та поліпшення якості навколишнього середовища» серед завдань Співтовариства ${ }^{6}$.

Принцип субсидіарності відіграє важливу роль в екологічній галузі, де законодавча та політична компетенція розподіляється між $Є С$ та державами-членами. Це означає, що державичлени несуть головну відповідальність за захист навколишнього середовища, і ЄС може діяти «лише настільки, наскільки цілі пропонованої дії не можуть бути у достатній мірі досягнуті державамичленами», але «можуть бути краще досягнуті на рівні Союзу» ${ }^{7}$. Крім того, ДФЄС дозволяє проводити регіональну диференціацію в галузі екологічної політики. Законодавство ЄС про навколишнє середовище не спрямоване на повну гармонізацію національного законодавства. Швидше, воно, як правило, встановлює мінімальні екологічні стандарти загального характеру, спрямовані на зближення національного. Однак, стаття 191 (3) ДФЄС пояснює, що охорона

\footnotetext{
${ }^{1}$ Sands, P. (1991). European Community Environmental Law: The Evolution of a Regional Regime of International Environmental Protection. The Yale Law Journal, 100, 8, 2511-2523.

${ }^{2}$ Koppen, I. (2013). The Role of the European Court of Justice. Environmental Policy in the European Union. Actors, Institutions, and Processes. London: Earthscan, 100-119.

${ }^{3}$ Eur-Lex (1981). Opinion in Cases 68/81 to 73/81: Commission v. Belgium <https://eur-lex.europa.eu/legal-content/ EN/TXT/?uri=CELEX:61981CC0068> (2021, червень, 30).

${ }^{4}$ Eur-Lex (1991). Case 300/89: Commission v. Council (Titanium Dioxide) <https://eur-lex.europa.eu/legal-content/ EN/TXT/?uri=CELEX\%3A61989CJ0300> (2021, червень, 30).

${ }^{5}$ Eur-Lex (1992). Treaty on European Union. Official Journal. Maastricht, 110.

${ }^{6}$ European Union (1997). Treaty of Amsterdam <https://europa.eu/european-union/sites/default/files/docs/body/ treaty_of_amsterdam_en.pdf> (2021, червень, 30).

${ }^{7}$ Eur-Lex (1957). Treaty Establishing the European Economic Community (EEC)

<https://eur-lex.europa.eu/legal-content/EN/ALL/?uri=CELEX\%3A11957E\%2FTXT> (2021, червень, 30).
} 
навколишнього середовища та європейська інтеграція повинні враховувати різноманітність екологічних, соціальних та економічних умов різних європейських «регіонів» ${ }^{1}$.

У цих рамках диференціація та гнучкість поступово стали головними рисами управління навколишнім середовищем у політиці ЄС. 3 одного боку, поступове розширення $Є С$ як з точки зору політичної компетенції, так і географічного масштабу- за рахунок розширень- ускладнило підтримку відносно централізованої та однорідної парадигми прийняття рішень, яка характеризувала попереднє Співтовариство. Стало очевидним, що ефективний інтеграційний процес у Свропейському Союзі, що розростається, також повинен враховувати різні передумови та зобов'язання різних держав-членів ${ }^{2}$.

«Новий» підхід до управління навколишнім середовищем на практиці перетворився на помітну «процедурність» відповідних екологічних зобов'язань ${ }^{3}$ та більш широке використання рамкових директив та заходів, які не зосереджені на конкретних природних ресурсах, наприклад, таких як законодавство про екологічну оцінку та громадський доступ до інформації, тощо. Відповідними прикладами є Директива ЄС про комплексне запобігання та контроль забруднення, Рамкова директива про якість повітря та Рамкова директива про води. Зосереджуючись на процедурних вимогах - таких, як дозволи, планування та зобов'язання щодо звітування - ці інструменти забезпечують більшу гнучкість та диференціацію не тільки на регуляторному рівні, але більш конкретно при виконанні екологічних зобов'язань. Цікаво, що диференціація відбувається не тільки між державами-членами або між регіонами у межах держави, але часто на рівні окремих підприємств.

Для ЄС переломним моментом стала підготовка до розширення державних суб'єктів 315 до 27. Наявність значних диспропорцій в економічних показниках старих та нових держав-членів також породжувало страх перед потенційним негативним впливом розширення на ефективність прийняття рішень $Є С$ та на рівень встановлення екологічних стандартів ${ }^{4}$. Хоча 3 іншого боку, розширення розглядалося як можливість підвищити рівень охорони навколишнього середовища у країнах-членах, що приєднуються ${ }^{5}$. Більше того, амбіційно, але виправдано буде допустити, що розширення на схід виступало каталізатором для більш інтенсивної взаємодії ЄС зі своїми найближчими сусідами та врешті-решт для розширення меж застосування екологічного законодавства за межі юрисдикції $\mathrm{CC}^{6}$.

Подальша Стратегія сталого розвитку СС у Гетеборзі та Шоста ПЕД (2002-2012 рр.) підсилюють акцент на сталому розвитку та екологічній інтеграції як загальній концептуальній парадигмі екологічної політики. Однак після прийняття Лісабонської стратегії у 2000 р. стало ясно, що справжній виклик на той момент полягав у тому, щоб вийти за межі риторичного наголосу на цих принципах і знайти конкретні шляхи узгодження лісабонських цілей конкурентоспроможності та економічного зростання із захистом навколишнього середовища.

Ще однією помітною подією стало прийняття Регламенту СС 1907/2006 всеохоплюючий режим щодо хімічних речовин у Свропі, а також встановлює конкретні зобов'язання та вимоги щодо реєстрації, оцінки та дозволу для виробників та імпортерів як відповідь на проблему незаконної вирубки. План дій з питань правоохоронної діяльності,

\footnotetext{
${ }^{1}$ Eur-Lex (1957). Treaty Establishing the European Economic Community (EEC)

<https://eur-lex.europa.eu/legal-content/EN/ALL/?uri=CELEX\%3A11957E\%2FTXT> (2021, червень, 30).

${ }^{2}$ Orlando, E. (2013). The Evolution of EU Policy and Law in the Environmental Field: Achievements and Current Challenges. The Transatlantic Relationship and the future Global Governance <http://www.iai.it/sites/default/files/TW_WP_21.pdf> (2021, червень, 30).

${ }^{3}$ Vogler, J. T (2009). The Evolution of EU Environmental Governance. Environmental Protection. European Law and Governance. Oxford: Oxford University Press, 1-26.

${ }^{4}$ Lee, M. (2005). The Transatlantic Relationship and the future Global Governance. Challenges, Change and Decision-Making. EU Environmental Law. Oxford and Portland: Hart; Bär, S., Homeyer, I., Klasing, A. (2001). Fit for Enlargement? Environmental Policy after Nice. European Environmental Law Review, 10, 7, 212-220.

${ }^{5}$ European Commission (2002). Ten Years After Rio: Preparing for the World Summit on Sustainable Development in 2002. <http://eur-lex.europa.eu/LexUriServ/LexUriServ.do?uri=celex:52001dc 0053:en:not> (2021, червень, 30). ${ }^{6}$ Vogler, J. (2005). The European Contribution to Global Environmental Governance. International Affairs, 81, 4, 835-850.

${ }^{7}$ Eur-Lex (2006). Regulation No 1907/2006 concerning the Registration, Evaluation, Authorisation and Restriction of Chemicals (REACH) <http://eur-lex.europa.eu/LexUriServ/LexUriServ.do?uri=celex:32006r1907:en:not> (2021, червень, 30).
} 
управління та торгівлі лісами (FLEGT) та відповідне конкретне законодавство, що його впроваджує встановлюють схему, що поєднує добровільні та обов'язкові зобов'язання щодо вирішення екологічних, соціальних та економічних наслідків від незаконної торгівлі деревиною.

Проте найвизначнішими аспектами екологічної політики $\mathrm{CC}$ на цьому етапі залишаються дії та ініціативи у відповідь на зміну клімату, визначені у Шостій ПЕД як «виклик на наступні 10 років і далі» ${ }^{1}$. Зміна клімату також $є$ однією із сфер екологічної політики, де взаємодія між ЄС та міжнародним рівнем $є$ найбільш очевидними. Спочатку з'явившись на підтримку розвитку подій на міжнародному рівні, екологічне законодавство та політика $Є С$ у галузі зміни клімату незабаром перетворились на суттєвий та конкретний пакет законодавчих заходів, спрямованих на «включення» проблем зменшення викидів у різні сектори та сфери політики, включаючи промисловість, транспорт, енергетику та будівельний сектор. Прийняття кліматичного та енергетичного пакету СС та дотримання цілей на 20-20-20 (з посиланням на скорочення викидів парникових газів, підвищення енергоефективності та кількості енергії, що походить від поновлюваних джерел) висвітлюють амбіційну позицію ЄС у цьому контексті ${ }^{2}$. А пов'язаний з цим побічний ефект зростаючої популярності та автономії, набутих кліматичною політикою ЄС, є iї поступовою відірваністю від сфери екологічної політики, що врештірешт завершилось створенням Генерального директорату з питань клімату.

Необхідність подальших зусиль для забезпечення виконання та інтеграції екологічних цілей в інші сфери політики, а також залучення зацікавлених сторін та громадян до природоохоронних дій стали основою для напрацювання сьомої ПЕД. Основним ключовим викликом майбутньої екологічної політики було визнано необхідність еволюції від санації до запобігання деградації Стійке зростання вимагало переходу до зеленої, ефективної з використання ресурсів, конкурентоспроможної та низьковуглецевої економіки, що зменшило б залежність ЄС від сировини та природних ресурсів (це було наголошено в Стратегії Європа 20204). Поведінка споживачів розглядалася як поле для подальших вдосконалень.

Зростаючий зовнішній вплив ЄС також спонукав Співтовариство відігравати більшу роль у формуванні міжнародної політики. $Є С$ взяв за ціль сприяти кращому глобальному екологічному управлінню та сталому зеленому зростанню (іншими словами, інтеграції екологічних, соціальних та економічних аспектів за його межі).

Це було складніше для реалізації, аніж раніше, адже зараз у ЄС було вже майже 30 країн, багато з яких намагалися впоратися з економічною кризою. Узгодженість між різними напрямками політики СС та пріоритетами потрібно було шукати на всіх етапах - від формулювання до реалізації. Враховуючи обмеженість державних бюджетів, покращення стану навколишнього середовища розглядалося як необхідність дедалі більшої залежності від поєднання державного та приватного сектору фінансування. Зусилля із поступового скасування шкідливих для навколишнього середовища субсидій та використання оподаткування для кращої підтримки стійкості також розглядалися як сфери, які слід включити до нової ПЕД 5 .

Відмітною характеристикою даного етапу еволюції екологічної політики $Є С$ є залучення зацікавлених сторін до формулювання сьомої ПЕД -національних органів влади, представників промисловості, НУО, асоціацій, громадян. Підхід розробки сьомої програми також був дещо інакшим - описувалися стан справ та виклики на майбутнє, а потім надавалися конкретні цілі та інструменти для досягнення цих цілей ${ }^{6}$.

\footnotetext{
${ }^{1}$ Eur-Lex (2002). Decision No 1600/2002/EC laying down the Sixth Community Environment Action Programme $<$ http://eur-lex.europa.eu/LexUriServ/LexUriServ.do?uri=celex:32002d1600:en:not> (2021, червень, 30).

${ }^{2}$ Council of the European Union (2008). Energy and climate package. Elements of the final compromise (17215/08). <http://www.consilium.europa.eu/uedocs/cmsUpload/st17215.en08.pdf> (2021, червень, 30).

${ }^{3}$ European Commission website (2019). The evolution of the EU environment and climate policy framework: from the 6th to the 7th EAP. Trinomics, 2. <https://ec.europa.eu/environment/action-programme/pdf/

7EAP_Issue_paper_2_evolution_6_to_7_EAP_final.pdf> (2021, червень, 30).

${ }^{4}$ Eur-Lex (2020). Europe 2020 A strategy for smart, sustainable and inclusive growth.

$<$ https://eur-lex.europa.eu/legal-content/en/ALL/?uri=CELEX\%3A52010DC2020> (2021, червень, 30).

${ }^{5}$ European Commission website (2019). The evolution of the EU environment and climate policy framework:

from the 6th to the 7th EAP. Trinomics, 2. <https://ec.europa.eu/environment/action-programme/pdf/

7EAP_Issue_paper_2_evolution_6_to_7_EAP_final.pdf> $(2021$, червень, 30).

6 Там само.
} 
Сьома ПЕД була розроблена для узгодження з політичними ініціативами $€ C$, пов'язаними 3 навколишнім середовищем, оскільки вона була побудована на основі стратегії Європа 2020, включаючи кліматичний та енергетичний пакет Союзу, Дорожню карту до енергоефективної Європи, Стратегію щодо біорізноманіття ЄС до 2020, Повідомлення щодо покращення надання переваг від екологічних послуг $\mathrm{CC}$, Повідомлення Комісії щодо Дорожньої карти переходу до низьковуглецевої економіки на $2050 \mathrm{p}^{1}$.

Останні два десятиліття міжнародні та зовнішні виміри екологічної політики стали частиною основних принципів дій $Є С$ у цій галузі. Хоча зусилля $Є С$ щодо підтвердження свого міжнародного лідерства особливо чіткі щодо галузі зміни клімату, зовнішні наслідки його дії помітні в інших сферах та стосовно різних аспектів екологічної політики. Зокрема, розглядаючи конкретні ініціативи, можна виявити різні аспекти ролі $Є С$ на міжнародному рівні та його внеску у глобальне управління навколишнім середовищем. Перший i, мабуть, найбільш прямий аспект стосується участі та провідної ролі ЄС у міжнародних екологічних угодах. У цьому відношенні ставлення ЄС традиційно орієнтоване на багатосторонність. ЄС розглядає свою міжнародну діяльність як вирішальну у сприянні швидкій ратифікації, ефективному дотриманню та виконанню міжнародних конвенцій та угод, що стосуються навколишнього середовища ${ }^{2} .3$ цієї точки зору ЄС відіграв провідну роль у прийнятті багатьох міжнародних екологічних договорів, включаючи Базельську конвенцію 1989 р. «Про транскордонне переміщення небезпечних відходів», Конвенцію 1992 р. «Про біологічне різноманіття», Стокгольмську конвенцію 2001 р. «Про стійкі органічні забруднювачі», зокрема Картахенський протокол про біобезпеку 2000 року та Кіотський протокол про зміну клімату 1997 року.

Інтеграція екологічних проблем та цілей у всі аспекти зовнішніх зв'язків Співтовариства та розвиток «глобального партнерства» у галузі навколишнього середовища та сталого розвитку з'явилися нещодавно як подальший вимір політики зовнішніх зв'язків СС та його інструменту «м'якої сили». ${ }^{3}$ Основними механізмами дій $Є С$ у цьому напрямку є двосторонні угоди, укладені в контексті Європейської політики сусідства (ЄПС) та євро-середземноморського партнерства, та політика розвитку та співробітництва ${ }^{4}$.

Варто зазначити, що екологічні програми ЄС є динамічними у своєму розвитку. Зокрема, уже у січні 2020 року почалася розробка Восьмої ПЕД ЄС. Ця нова 10-річна програма зберігає бачення з 7-ї ПЕД, прагнучи пришвидшити перехід ЄС до кліматично нейтральної, ефективної у ресурсах, чистої економіки справедливим та всеохоплюючим способом, повністю підтримуючи екологічні та кліматичні цілі Свропейського зеленого курсу5.

Восьма ПЕД має шість пріоритетних цілей у таких сферах: кліматична нейтральність, адаптація та стійкість до змін клімату та інших екологічних ризиків; збереження та відновлення біорізноманіття та екосистем; циркулярна економіка та модель регенеративного зростання, що відокремлює економічне зростання від використання ресурсів та деградації навколишнього середовища; зведення до нульового забруднення; та зменшення екологічного тиску з боку виробництва та споживання 6 .

Пріоритет останніх екологічних програм ЄС стосується глобальних викликів. Багато пріоритетних цілей у ПЕД можна досягти лише у співпраці з країнами-партнерами або як частину глобального підходу. ЄС та його держави-члени прагнуть ефективніше брати участь у роботі

\footnotetext{
${ }^{1}$ European Commission website (2019). The evolution of the EU environment and climate policy framework: from the 6th to the 7th EAP. Trinomics, 2. <https://ec.europa.eu/environment/action-programme/pdf/

7EAP_Issue_paper_2_evolution_6_to_7_EAP_final.pdf> (2021, червень, 30).

${ }^{2}$ Eur-Lex (2002). Decision No 1600/2002/EC laying down the Sixth Community Environment Action Programme. $<$ http://eur-lex.europa.eu/LexUriServ/LexUriServ.do?uri=celex:32002d1600:en:not> (2021, червень, 30).

${ }^{3}$ Eur-Lex (2020). On the sixth environment action programme of the European Community. European Commission. <http://eur-lex.europa.eu/LexUriServ/LexUriServ.do?uri=celex:52001pc0031:en:not> (2021, червень, 30).

${ }^{4}$ Marín, D., Morgera, E. (2012). Environmental Integration in the EU's External Relations. Beyond Multilateral Dimensions. Oxford and Portland, Hart.

${ }^{5}$ European Commission (2019). A European Green Deal <https://ec.europa.eu/info/strategy/priorities-2019-2024/ european-green-deal_en> (2021, червень, 30).

${ }^{6}$ European Commission (2020). Environment action programme to 2030.

<https://ec.europa.eu/environment/strategy/environment-action-programme-2030_en> (2021, червень, 30).
} 
3 міжнародними партнерами щодо прийняття Цілей сталого розвитку як продовження конференції «Ріо + 20». ПЕД також пропонує вивчати попередні програми і планувати подальші кроки 3 точки зору зменшення впливу на навколишнє середовище поза межами ЄС.

За останні чотири десятиліття СС прийняв понад двісті підзаконних актів у цій галузі. На міжнародному рівні ЄС є учасником понад сорока багатосторонніх екологічних угод і часто активно підтримує екологічні стандарти в екологічних переговорах. Лісабонський договір підтвердив прихильність $Є С$ до захисту навколишнього середовища та сталого розвитку та чітко наголошує на внутрішніх та зовнішніх вимірах дій $С С$ у цій галузі. Тим не менше, для вирішення низки важливих проблем $С$ С повинен відігравати значну роль у захисті навколишнього середовища та затвердити себе як лідер у глобальних процесах управління навколишнім середовищем.

Як бачимо із міжнародного та європейського досвіду, підходи до формування екологічної політики змінювалися відповідно до потреб часу. У цілому, з початку 1970-х років екологічна політика у своїх концептуальних підходах здійснила перехід від прийняття конкретних рішень до підходу запобігання та контролю. Такий підхід покладається на пом'якшення негативних наслідків.

До принципів, що були визначені Ріо-де-Жанейрською декларацією додамо ще наступні:

- принцип «забруднювач платить», який адресує альтернативні витрати тим суб'єктам господарської діяльності, з вини яких вони виникли;

- принцип довготривалої перспективи (наприклад, стратегічна оцінка впливу на довкілля);

- принцип альтернативних витрат;

- принцип єдності екосистем, який вимагає комплексного підходу до формування екологічної політики;

- принцип запобіжних заходів;

- принцип стійкого розвитку (тобто такої моделі розвитку, за якої при плануванні та здійсненні будь-якої діяльності враховуються як економічні, так і соціальні та екологічні фактори) ${ }^{1}$.

Незважаючи на значну інституційну різноманітність між державами-членами Європейського Союзу, можна відзначити загальну модель використання добровільних підходів щодо екологічної політики. У зв'язку з цим більшість країн використовують переговори на національному рівні, між урядом та коаліцією компаній чи підприємств, переважно представлених галузевою організацією.

\section{References:}

1. Bär, S., Homeyer, I., Klasing, A. (2001). Fit for Enlargement? Environmental Policy after Nice. European Environmental Law Review, 10, 7, 212-220. [in English].

2. Benson, D., Jordan, A. (2015). Environmental Policy. International Encyclopedia of Social and Behavioural Sciences. Oxford: Elsevier. [in English].

3. Council of the European Union (2008). Energy and climate package. Elements of the final compromise (17215/08). <http://www.consilium.europa.eu/uedocs/cmsUpload/st17215.en08.pdf> (2021, June, 30). [in English].

4. Eur-Lex (1957). Treaty Establishing the European Economic Community (EEC) <https://eur-lex.europa.eu/ legal-content/EN/ALL/?uri=CELEX\%3A11957E\%2FTXT> (2021, June, 30). [in English].

5. Eur-Lex (1981). Opinion in Cases 68/81 to 73/81: Commission v. Belgium <https://eur-lex.europa.eu/legal-content/ EN/TXT/?uri=CELEX:61981CC0068> (2021, June, 30). [in English].

6. Eur-Lex (1987). Resolution on the continuation and implementation of a European Community policy and action programme on the environment <http://eur-lex.europa.eu/LexUriServ/LexUriServ.do?uri=celex:41987x1207:en:not> (2021, June, 30). [in English].

7. Eur-Lex (1991). Case 300/89: Commission v. Council (Titanium Dioxide) <https://eur-lex.europa.eu/legal-content/ EN/TXT/?uri=CELEX\%3A61989CJ0300> (2021, June, 30). [in English].

8. Eur-Lex (1992). Treaty on European Union. Official Journal. Maastricht, 110. [in English].

9. Eur-Lex (2002). Decision No 1600/2002/EC laying down the Sixth Community Environment Action Programme <http://eur-lex.europa.eu/LexUriServ/LexUriServ.do?uri=celex:32002d1600:en:not> (2021, June, 30). [in English].

10. Eur-Lex (2006). Regulation No 1907/2006 concerning the Registration, Evaluation, Authorisation and Restriction of Chemicals (REACH) <http://eur-lex.europa.eu/LexUriServ/LexUriServ.do?uri=celex:32006r1907:en:not> (2021, June, 30). [in English].

11. Eur-Lex (2020). Europe 2020 A strategy for smart, sustainable and inclusive growth. <https://eur-lex.europa.eu/legal-content/en/ALL/?uri=CELEX\%3A52010DC2020> (2021, June, 30). [in English].

1 Зырянова, У., Кузнецов, В., Лазарев, В. (2011). Основные принципы и инструменты экологической политики.

Экономика природопользования. Ульяновск: УлГТУ, 73-84. 
12. Eur-Lex (2020). On the sixth environment action programme of the European Community. European Commission. <http://eur-lex.europa.eu/LexUriServ/LexUriServ.do?uri=celex:52001pc0031:en:not> (2021, June, 30). [in English].

13. European Commission (2002). Ten Years After Rio: Preparing for the World Summit on Sustainable Development in 2002. <http://eur-lex.europa.eu/LexUriServ/LexUriServ.do?uri=celex:52001dc 0053:en:not> (2021, June, 30). [in English].

14. European Commission (2019). A European Green Deal <https://ec.europa.eu/info/strategy/priorities-2019-2024/ european-green-deal_en> (2021, June, 30). [in English].

15. European Commission (2019). The evolution of the EU environment and climate policy framework: from the 6 th to the 7 th EAP. Trinomics, 2. <https://ec.europa.eu/environment/action-programme/pdf/ 7EAP_Issue_paper_2_evolution_6_to_7_EAP_final.pdf> (2021, June, 30). [in English].

16. European Commission (2020). Environment action programme to 2030. $<$ https://ec.europa.eu/environment/strategy/environment-action-programme-2030_en> (2021, June, 30). [in English].

17. European Union (1997). Treaty of Amsterdam <https://europa.eu/european-union/sites/default/files/docs/body/ treaty_of_amsterdam_en.pdf $>$ (2021, June, 30). [in English].

18. Hanf, K. (1997). Air Pollution Policy in the European Union. Environmental Law and Policy in the European Union and the United States, 125-146. [in English].

19. Holovkin, O. (2011). Derzhavnyy kontrol ta nahlyad v sferi okhorony dovkillya yak skladova ekolohichnoyi polityky Ukrayiny [State control and supervision in the field of environmental protection as a component of Ukraine's environmental policy]. Chasopys Kyyivskoho universytetu prava [Journal of Kyiv University of Law], 4, $290-293$. [in Ukrainian].

20. Konferentsia Organizatsii Obyedinennykh Natsiy po problemam okruzhayushchey cheloveka sredy [United Nations Conference on the Human Environment] (1970). Stokgolmskaya deklaratsiya [Stockholm Declaration] $<$ https://www.un.org/ru/documents/decl_conv/declarations/declarathenv.shtml> (2021, June, 30). [in Russian].

21. Koppen, I. (2013). The Role of the European Court of Justice. Environmental Policy in the European Union. Actors, Institutions, and Processes. London: Earthscan, 100-119. [in English].

22. Lackey, R. (2006). Axioms of ecological policy. Fisheries, 31 (6), 286-290. [in English].

23. Lee, M. (2005). The Transatlantic Relationship and the future Global Governance. Challenges, Change and Decision-Making. EU Environmental Law. Oxford and Portland: Hart. [in English].

24. Malish, N. A. (2009). Ekolohichna polityka: konfliktnist, stratehiya, taktyka. [Environmental policy: conflict, strategy, tactics]. Visnyk Natsionalnoyi akademiyi upravlinnya pry Prezydenti Ukrayiny [Bulletin of the National Academy of Management under the President of Ukraine], 1, 1-7. [in Ukrainian].

25. Marín, D., Morgera, E. (2012). Environmental Integration in the EU's External Relations. Beyond Multilateral Dimensions. Oxford and Portland, Hart. [in English].

26. Movchan, Yu (2021). Polityka YeS u sferi okhorony dovkillya [EU environmental policy]. Ofitsiynyy sayt Ministerstva yustytsiyi Ukrayiny [Official site of the Ministry of Justice of Ukraine] $<$ https://minjust.gov.ua/m/str_2971> (2021, June, 30). [in Ukrainian].

27. Orlando, E. (2013). The Evolution of EU Policy and Law in the Environmental Field: Achievements and Current Challenges. The Transatlantic Relationship and the future Global Governance. <http://www.iai.it/sites/default/files/TW_WP_21.pdf> (2021, June, 30). [in English].

28. Postalovskaya, O. (2016). Instituty i mekhanizmy realizatsii ekologicheskoy politiki v sovremennom obshchestve [Institutions and mechanisms for the implementation of environmental policy in modern society]. Minsk. [in Russian].

29. Sands, P. (1991). European Community Environmental Law: The Evolution of a Regional Regime of International Environmental Protection. The Yale Law Journal, 100, 8, 2511-2523. [in English].

30. Vogler, J. (2005). The European Contribution to Global Environmental Governance. International Affairs, 81, 4, 835-850. [in English].

31. Vogler, J. T (2009). The Evolution of EU Environmental Governance. Environmental Protection. European Law and Governance. Oxford: Oxford University Press, 1-26. [in English].

32. Volynets, V. (2012). Ekolohichna funktsiya v systemi funktsiy derzhavy: problemy pravovoho zabezpechennya v Ukrayini [Ecological function in the system of state functions: problems of legal support in Ukraine]. Yurydychna Ukrayina [Legal Ukraine], 11, 4-11. [in Ukrainian].

33. Weale, A. (1996). Environmental Rules and Rule-Making in the European Union. Journal of European Public Policy, 3, 4, 594-611. [in English].

34. Zyryanova, U., Kuznetsov, V., Lazarev, V. (2011). Osnovnyye printsipy i instrumenty ekologicheskoy politiki [Basic principles and instruments of environmental policy]. Ekonomika prirodopolzovaniya [Environmental economics]. Ulyanovsk: UISTU, 73-84. [in Russian]. 